\title{
NEED OF THE STEWARDSHIP CODE: A RELOOK ON KOTAK COMMITTEE'S REPORT
}

\author{
Amit K Kashyap \\ Assistant Professor of Law, Head Centre for Corporate Law Studies, Institute of Law, \\ Nirma University, Ahmedabad, Gujarat, India
}

Karan Parihar

Advocate, Rajasthan High Court, Jodhpur, Rajasthan, India

\begin{abstract}
The theory of Stewardship is not the new concept but it came in the light in 2010 when UK established its UK Stewardship code, which became the model code for many countries who made the code in their country on the line of UK code. The code comprises set of principles on how institutional investors are ought to act as shareholders of companies. This code works on the 'comply or explain' approach. This holds relevance in the backdrop of several irregularities found in the governance of many companies and several scams took place relating to the institutional investors. This topic became relevant in India after Uday Kotak Committee report on the corporate governance which recommended common Stewardship Code across sectors. Moreover, UK-India Financial Partnership also recommended for the same.

In the light of the above needs, India must have a Stewardship Code based on the principle of transparency and accountability. India should frame its code based on the best international practices and also taking into consideration the special needs of the Indian Capital Market. This code will help in setting the accountability to the institutional investors. They need to participate in the investee company by way of voting and by way of participation in the meeting, which will help the ultimate investor's investment. This in a way will helpful for the Investee Company as well as for the investors/ beneficiaries.
\end{abstract}

This paper focuses on a particular manifestation of this positive view of shareholder engagement as per stewardship code envisaged by Kotak Committee Panel and emergence of shareholders activism in India.

Key words: Corporate Governance, Kotak Committee, Stewardship, Shareholders Activism.

Cite this Article: Amit K Kashyap and Karan Parihar, Need of the Stewardship Code: A Relook on Kotak Committee's Report, International Journal of Management, 11(12), 2020, pp. 2063-2073.

https://iaeme.com/Home/issue/IJM?Volume=11\&Issue $=12$ 


\section{INTRODUCTION}

"The most powerful enforcement body in the corporate system is the shareholder body. Via pension funds, provident funds, insurance products and other group investments, the public makes up the largest owner of many publicly listed companies"

-King Report 2002

The relationship between various stakeholders of the business while carrying out the commercial has been described by various theories like, Agency Theory, Stewardship Theory, Resource Dependency Theory, Stakeholder Theory, Transaction Cost Theory and Political Theory etc. Most theories of corporate governance use personal self interest as a starting point. Among all these theories the stewardship theory has biggest agenda which says that that ownership doesn't really own a company; it's merely holding it in trust. Corporate Governance is no more a topic of academic discussions moving around these theories, but has moved to political agendas of economies worldwide. States are making stringent laws to govern the business activities in interest of not only the owners but for all stakeholders.

Corporate Governance has been hitting headline in India for quite some times, particularly post Satyam scam. Satyam scam has given lessons to regulators and has pushed the agenda for wholistic reforms in corporate governance landscape in India. People like K.M. Birla, Narayan Murthy and Naresh Chandra have given extensive reports on corporate governance. They have emphasized the importance of a good corporate governance cycle in the Indian corporate culture so that we have a robust mechanism. Nevertheless, there have been many loopholes in the corporate governance regime in most of the major public listed companies. A few other reasons being (1).

- Tremendous change in the market

There has been a sudden change in the market conditions off late. There could not only be physical, in terms of stock markets, etc but also changes in the demography, technology and other factors.

- More importance to short term than long term goals

Suddenly, most of the corporates haves started a regime of targeting quarters rather than concentrating on more than keeping their aim for the entire financial year.

- Complex environment

With the ever dynamic market, the regulations and laws tend to get complicated day by day and do not leave any scope of relaxation.

- Too much time wasted in reviewing instead of offering solutions

Instead of giving out deliberate solutions, the boards of various companies, put a mirror show in understanding the various lacunas.

- Transparency issues

Since the market is always on the verge of a change, thee always transparency issues with the understanding of the same.

With the view of improving corporate governance standards of listed companies in India, the capital market regulator in India constituted a new committee for further reforms and to take immediate actions. In June, 2017, the SEBI constituted a committee on Corporate Governance for ensuring a legal parameter for the Corporate Governance in the corporate sector of India. This committee was led by Mr. Uday Kotak who had submitted its report with a number of recommendations in the Corporate Governance, on which the SEBI had demanded a public comment till $5^{\text {th }}$ November, 2017.(2) Recommendations of the committee has been primarily inspired by stewardship theory. 


\section{STEWARDSHIP THEORY: AN OVERVIEW}

Stewardship is a noble concept which directly refers to the active involvement of shareholders in the governance of corporation. In such an environment, the goal of corporate law became one of protecting shareholder interests, rather than providing them with participation rights.(3)

"Stewardship theory draws from sociology and psychology to offer an alternate view in which organizational actors see greater long-term utility in other focused prosocial behavior than in self-serving, short-term opportunistic behavior". (4)

Stewardship is all about placing the long-term best interests of a group ahead of personal goals that ultimately serves an individual's self-interest. It reflects an ongoing sense of obligation or duty to investors based on the intention to uphold the covenantal relationship between Investee Company and investors. (5) The basic idea of stewardship in based in standard principles of good governance designed to assist the institutional investors and proxy firms to assume the responsibility of investors protections and watch over shareholders wealth maximization in corporation.

Stewardship code is a set of principles or guidelines focus mainly on institutional investors, who hold shares, and voting rights in companies. They hold a fiduciary relationship with the companies on behalf of real beneficiaries. Thus this requires investors to monitor and engage with companies on material matters, including social, governance, strategy, performance etc. and also vote their shares at AGMs and EGMs. (6)

It is designed to assist institutional investors and their service providers in fulfilling their responsibilities to their clients to protect and enhance the value that accrues to them. These principles are intended to allow flexibility in their application. The code work on the "comply or explain' approach, which implies that the institutional investors either comply with the code or if they do not comply, then they have to explain the reasons publicly for not complying with the same. (7)

Many countries have drafted the regulations for shareholders and their right to participate in corporate governance around the world. The rise of powerful Institutional investors and proxy firms in India has been a catalyst in the augmentation of stewardship code in India.

\section{STEWARDSHIP CODE: COMPARISON OF INDIA, US \& UK}

The Corporations have become dominant and powerful institutions after the emergence of globalization. Fewer governmental control over the deterritorialised corporations and expansions of multinational corporations at all corners of globe has raised more concerns for accountability and transparency. In this complex global environment, the governance of these giant commercial organizations needs to address both economic and non-economic activities. The corporations need to look after needs of stakeholders including but not limited to employees, shareholders, creditors, customers, government, business partners and society.

Several countries such as United Kingdom, Japan, Malaysia, etc. have prescribed detailed Stewardship Codes which needs to be followed by institutional investors on a voluntary basis. These Codes are based on certain principles applicable to institutional investors, which require that investors have clear and comprehensive policies on:

- Discharge of their stewardship responsibilities

- Management of conflicts of interest in fulfilling stewardship responsibilities

- Monitoring of investee companies

- Intervention in investee companies

- Collaboration with other institutional investors 
- Voting and disclosure of voting activity

- Periodical reporting on their stewardship activities. (8)

\subsection{Position in UK}

There are at least 10 'stewardship codes' globally which are mainly modelled on the UK approach.(9) In 2010 UK's Financial Reporting Council published the first 'stewardship code', in response to lessons learned from the financial crisis.(10) This is based on the "comply or explain" approach, under which institutional investors report on their policies for monitoring and engaging with the companies in which they invest with the aim to improve the quality of dialogue to help improve long-term risk-adjusted returns to shareholders. The UK Stewardship Code also aims to make investors more accountable to their clients and beneficiaries. It sets out areas of good practice which the Financial Reporting Council (FRC) believes to be good for institutional investors. Also, The Financial Conduct Authority (FCA) requires asset managers to disclose on whether they apply the Code or not. Normally it is updated after every two years to ensure their relevancy. Moreover, Changes are only made after extensive consultation with the market. The most recent UK Stewardship Code was published in September 2012. (11) Currently this code has approximately 300 signatories including leading institutional investors. (12)

Under the UK Stewardship Code, Institutional investors should:

- "publicly disclose their policy on how they will discharge their stewardship responsibilities.

- have a robust policy on managing conflicts of interest in relation to stewardship and this policy should be publicly disclosed.

- monitor their investee companies.

- establish clear guidelines on when and how they will escalate their activities as a method of protecting and enhancing shareholder value.

- be willing to act collectively with other investors where appropriate.

- have a clear policy on voting and disclosure of voting activity.

- report periodically on their stewardship and voting activities".

\subsection{Position in US}

In January 2018, many large and influential investors launched the Investor Stewardship Group. They come with stewardship framework, which has rapidly gained momentum among US institutional investors and are effective from $1^{\text {st }}$ January 2018(14). These are based on the Corporate Governance Framework for U.S. Listed Companies, which includes accountability $\&$ responsibility of Board, rights and powers of the shareholders, efficient structure of Board (15).

Following are the Principles of Stewardship Framework for Institutional Investors are-

- "Institutional investors are accountable to those whose money they invest.

- They should demonstrate how they evaluate corporate governance factors with respect to the companies in which they invest.

- They should also disclose, in general terms, how they manage potential conflicts of interest that may arise in their proxy voting and engagement activities.

- They are responsible for proxy voting decisions and should monitor the relevant activities and policies of third parties that advise them on those decisions. 
- They should address and attempt to resolve differences with companies in a constructive and pragmatic manner.

- They should work together, where appropriate, to encourage the adoption and implementation of the Corporate Governance and Stewardship Principles". (16)

\subsection{Position in India}

In India, although considerable progress has been made in improving Indian corporate governance in recent years, the progress towards the creation of 'stewardship code' has been limited. Moreover, there is no specific provision for a 'stewardship code' under SEBI LODR Regulations (17). One of the first steps in the direction of Stewardship code was taken by SEBI while prescribing the detailed requirements for disclosures with respect to voting policies and actual voting on different resolutions of investee companies by mutual funds in India (18). Also, Insurance Regulatory Development Authority in March 2017 launched guidelines for 'stewardship code' for Indian insurers, who are one of the most important investors in India's capital markets, on the furtherance of SEBI issuance of voting disclosure guidelines to mutual fund in 2010 (19). Also, SEBI has already set out some rules for asset management firms and has been encouraging to vote in company resolutions and disclose their policies to exercise such votes (20). But in India, there is no common stewardship code yet that is applicable to all institutional investors.

The Financial Stability and Development Council (FSDC) established the committee under the chairmanship of SEBI with representatives of IRDA and Pension Fund Regulatory and Development Authority (PFRDA) to consider the establishment of a 'stewardship code' in India. They submitted their report which is FSDC's approval. Meanwhile Kotak report also recommended 'common stewardship code' for the entire financial sector on the lines of global best practices. In 2017, the India- UK Financial Partnership of which Uday Kotak was Cochair, also recommended to develop Indian Stewardship Code, a voluntary, principles based on 'comply or explain' theory and a 'voting plus framework'. (21)

Presently under IRDA Stewardship Code- insurers are required to put in place, maintain and publicly disclose a policy for identifying and managing conflicts of interest with the aim of taking all reasonable steps to put the interests of their client first. The policy should identify scenarios of conflict of interest as envisaged by the Board and should also address how matters are handled when the interests of clients or beneficiaries diverge from each other (22).

There are some Issues pertaining to the different institutional investor such as: Pension funds, which generally vote on company resolutions but there is a problem relating to the disclosures about their voting policies and decisions. Same way, Insurance companies, which accounts for the largest domestic institutional investors, have a poor track record on voting. Only Life Insurance Corp. of India (LIC) and a few other insurers vote on the investee companies, but they don't have a proper disclosure on their voting and decision (23).

\subsection{OECD Principle on Stewardship}

OECD recommend that the Institutional investors should disclose their policies with respect to corporate governance, voting policy at shareholder meetings, which is only channel for shareholder engagement. It also focuses on the direct contact and dialogue with the board and management (24).

Following are the Principles given by the OECD in relation with the Stewardship code-

- Institutional investors should disclose their corporate governance and voting policies with respect to their investments, including the procedures on the use of their voting rights, while acting in a fiduciary capacity. 
- Votes should be cast by investor in line with the directions of the beneficial owner of the shares.

- Institutional investors acting in a fiduciary capacity should disclose how they manage material conflicts of interest that may affect the exercise of key ownership rights regarding their investments (25).

\section{KOTAK REPORT AND STEWARDSHIP CODE}

Uday Kotak Committee also felt the need for Stewardship Code for India, while dealing the issue of corporate governance. They acknowledge the stewardship role played by asset managers who hold fiduciary responsibilities towards their own investors. Thus, there is the need to discharge the duties on both sides then only corporate governance agenda will be served (26). The committee formed on June 2, 2017 under the leadership of Mr. Uday Kotak with membership from academia, regulators, industry, policy makers, stock exchange and lawyers etc. submitted its report in the year 2017. The Kotak Panel has recommended several reforms like splitting the post of chairman and managing director, tighter rules for independent directors, enhanced disclosure of related-party transactions and mandatory secretarial audits for listed entities and their material subsidiaries.

The report of Kotak panel also has been significant in light of recent boardroom battles at some of the biggest Indian corporate houses, including Tata Group, Fortis Healthcare and Infosys which resulted in big reforms for governance of Independent Directors role in corporate world.

In view of the increasing emergence of institutional investors in capital markets across the world, they are expected to have a greater responsibility towards their clients/ investors by enhancing their monitoring and engagement with their investee companies. Such activities are referred as 'Stewardship Responsibilities' of institutional investors. Stewardship plays a pivotal role in efficient corporate governance which is ultimately crucial for bolstering India's economic growth. Thus, it is the part of the corporate governance strategy of the investee companies. Moreover, if the stewardship responsibilities are properly been taken care of, by the institutional investors, then it will help to protect the interests of the retail investors (27).

The Committee has recommended a common stewardship code for the entire financial sector in India on the lines of best practices globally based on the seven principles of stewardship. The Committee also recommends that since SEBI is the capital market regulator and the Code applies to investments in the capital market, thus SEBI is the right authority to introduce to protect investments by institutional investors in Indian capital markets (28). The stewardship code requires non-controlling shareholders mostly institutional investors like insurance companies, mutual funds, hedge funds to be transparent about their investments and disclose their process of involvement in corporate governance. To improve the scenario of stewardship in corporate governance the kotak panel has recommended measures to ensure institutional investors active involvement make the companies more responsive to transparency, shareholders democracy and disclosure requirements

The stewardship code is relevant in a scenario which have strong legal provisions for greater stakeholders involvement and protection of investors. In this context, the stewardship code to be success in India needs to including the rights of shareholders to 'participate in, and to be sufficiently informed of, decisions concerning fundamental corporate changes' and a principle requiring the 'protection of minority shareholders from abusive actions by, or in the interest of, controlling shareholdings either directly or indirectly, and effective means of redress' (29).

The Kotak panel has made many recommendations for strengthening stewardship code which has been accepted by SEBI. These recommendations have been implemented by making 
amendment in existing SEBI (Listing Obligations and Disclosure. Requirements) Regulations, 2018 (SEBI LODR). The recommendation will reinforce the active participation of investors and stakeholders in corporate governance. The key take ways are:

- Separation of CEO/MD and Chairperson

- Top 100 companies required Annual General Meetings within 5 months after the end of financial year.

- Top 100 companies compulsorily need to webcast of Annual General Meetings

- For royalty/brand payments to related party exceeding 2 percent of consolidated turnover, the approval Shareholder (majority of minority) is necessary.

- The listed companies have to disclose transactions with related parties on half yearly basis within 30 days of publication of results, on its website.

- Disclosure regarding utilisation of funds raised through QIP/ preferential issue

- No voting rights to be attached to existing treasury stock

- $50 \%$ of the board members be independent directors as compared to the current requirement of $33 \%$.

- Shareholders' approval with special majority special resolutions for any disposal of a controlling interest in a 'material subsidiary' or any transfer of a significant portion of such subsidiary's assets.

In today financial market, the investment chain is mostly long and complicated, with numerous intermediaries. Also, institutional investors such as mutual funds, pension funds, insurance companies and hedge fund have large investments in the different companies and most of the times they have asset managers to manage their holdings. All the institutional investors engage in corporate governance differently, like for some investors, engagement in corporate governance, including the exercise of voting rights, is a part of their business \& investment model and for others might spending their resources on active shareholders engagement is not a good idea, they just want the profit out of their investment. If shareholder engagement is not part of any institutional investor investment strategy then Regulator should try for mandatory requirements to engage them, through voting or through decision making (30).

The independent directors in a company are expected to protect the stakeholders interest, above all the minority shareholders. In this line, the kotak panel has substantiates that duty. The amended provisions of SEBI LODR also mandate the Listed companies to make disclosures for resignation of auditor/ independent director and mention the reasons thereof with the stock exchanges (31).

\section{OPINION AND SUGGESTION}

According to me, there is the need of Stewardship Code in the Indian Capital Market on the lines of the best international practices including OECD principles and UK stewardship code but on the same time we should take into consideration special features of Indian capital market, while framing the Indian Stewardship code, these includes- role of asset managers who are part of conglomerates with multiple and diverse business; and also at the same time many asset managers are state owned \& controlled (32).

This code should focus on engaging both Investors and Investees. Shareholders engagement should be the main focus of the Indian Stewardship code, which goes beyond voting at general meetings. Investors are expected to engage with company, to provide with the reasoning of their decision and recommendations. It promotes environment of confidentiality and trust to help mutual understanding (33). 
Institutional investor should have predefined policy on how they will take the decisions and will vote at the investee companies, which will give the idea to the investors and will promote transparency and fairness in the working of the investors as well as Investee Company (34). If there is a conflicting interest in voting and in other matters, then it is necessary to find those interest and the possible way to manage those conflicts by remaining in the framework of the policy, also that does not prejudice the best interests of clients and customers (35).

Thus, the primary purpose of the Indian code should be-

- Encourage all institutional investors to vote regularly and taking into consideration the interest of their investors.

- Provide a generally accepted framework which allowed the mechanism for responsible shareholder engagement,

- Provide for the room for discussions in Indian boardrooms in respect of investor view on relevant issues and improve the accountability of Indian boards of their shareholders,

- improve the quality of investment decisions by investors in Indian companies and

- finally strengthen the confidence of Indian retail investors and foreign investors in the integrity of Indian capital markets by their participation, and decisions in the important matters of the company which are also crucial for the investors (36).

There is a need for an effective Indian Stewardship Code which is important for transparency and accountability throughout the stewardship, because it results in enhanced investor returns over the long term and lower cost of capital for Indian companies, it also helps companies to have a high standard of corporate governance (37).

Moreover, In the process of accountability to clients, investors and beneficiaries under Indian Stewardship code, institutional investors need to give consideration to the frequency of reporting. It is useful if they add a new section dedicated to stewardship in the website and also they should identify the person responsible for such affairs (38).

\section{CONCLUSION}

In India there is a need to Common stewardship code in India, and it must include activities related to monitoring and engaging with companies on matters such as strategy, performance, risk, capital structure and corporate governance, remuneration of directors and management." (39).

Also, Institutional Investors should have a clear policy on voting and disclosures of voting activity and on managing the conflicts of interest, if any in fulfilling their stewardship responsibilities. They should monitor the affairs of investee companies and also have a clear policy on intervention in their investee companies. It is better if they have a clear policy for collaboration with other institutional investors, where required to preserve the interests of the ultimate investors (40).

\section{KEY NOTES}

(1) SEBI report on Corporate Governance. (www.sebi.gov.in)

(2) Omkar Goswami, Corporate Governance: Form Substance, And Turf Wars, (October 10, 2016), https://www.bloombergquint.com/opinion/2017/11/08/demonetisations-economic-impact-15billion-on-3-vital-sectors

(3) Hill, J. (2017). Good Activist/Bad Activist: The Rise of International Stewardship Codes. Legal Studies Research Paper. [online] Sydny: European Corporate Governance Institute. Available at: https://ecgi.global/sites/default/files/working_papers/documents/hillincl-sydney-cover.pdf [Accessed 8 Apr. 2019]. 
(4) MORELA HERNANDEZ, TOWARD AN UNDERSTANDING OF THE PSYCHOLOGY OF STEWARDSHIP, The Academy of Management Review, Vol. 37, No. 2 (April 2012), pp. 172193, Academy of Management, https://www.jstor.org/stable/23218837

(5) MORELA HERNANDEZ, TOWARD AN UNDERSTANDING OF THE PSYCHOLOGY OF STEWARDSHIP, The Academy of Management Review, Vol. 37, No. 2 (April 2012), pp. 172193, Academy of Management, https://www.jstor.org/stable/23218837

(6) Model Stewardship Code: For all Indian Institutional Investors- IiAS \& Cyril Amarchand Mangaldas joint initiative, June 5, 2017, https://www.iiasadvisory.com/singlepost/2017/06/05/Model-Stewardship-CodeFor-All-Indian-Institutional-Investors--IiAS-andCyril-Amarchand-Mangaldas-joint-initiative

(7) Guy R. Jubb and Nirmal Mohanty, An Indian Stewardship Code: Imperatives and Challenges, NSE Quarterly, NSE, Centre for Excellence in Corporate Governance, October 2017, No.19

(8) Uday Kotak, Report submitted by the Committee on Corporate Governance, October 2017, http://www.nfcg.in/UserFiles/KOTAKCOMMITTEREPORT.pdf

(9) Guy R. Jubb and Nirmal Mohanty, An Indian Stewardship Code: Imperatives and Challenges, NSE Quarterly, NSE, Centre for Excellence in Corporate Governance, October 2017, No.19

(10) Guy R. Jubb and Nirmal Mohanty, An Indian Stewardship Code: Imperatives and Challenges, NSE Quarterly, NSE, Centre for Excellence in Corporate Governance, October 2017, No.19

(11) International Corporate Governance Code - ICGC, By Institute of Company Secretaries of India

(12) Guy R. Jubb and Nirmal Mohanty, An Indian Stewardship Code: Imperatives and Challenges, NSE Quarterly, NSE, Centre for Excellence in Corporate Governance, October 2017, No.19

(13) The U K Stewardship C od"e, Financial Reporting Council, July 2010

(14) Guy R. Jubb and Nirmal Mohanty, An Indian Stewardship Code: Imperatives and Challenges, NSE Quarterly, NSE , Centre for Excellence in Corporate Governance, October 2017, No.19

(15) Mike McCauley, INVESTOR STEWARDSHIP IN THE UNITED STATES https://www.isgframework.org/wpcontent/uploads/2017/07/InvestorStewardshipintheUnitedStates.pdf

(16) Mike McCauley, INVESTOR STEWARDSHIP IN THE UNITED STATES https://www.isgframework.org/wpcontent/uploads/2017/07/InvestorStewardshipintheUnitedStates.pdf

(17) Uday Kotak, Report submitted by the Committee on Corporate Governance, October 2017, http://www.nfcg.in/UserFiles/KOTAKCOMMITTEREPORT.pdf

(18) Uday Kotak, Report submitted by the Committee on Corporate Governance, October 2017, http://www.nfcg.in/UserFiles/KOTAKCOMMITTEREPORT.pdf

(19) Guy R. Jubb and Nirmal Mohanty, An Indian Stewardship Code: Imperatives and Challenges, NSE Quarterly, NSE, Centre for Excellence in Corporate Governance, October 2017, No.19

(20) Jayshree P. Upadhyay, India to draft rules for institutional investors voting on company matters, https://www.livemint.com/Companies/0teJ9go8GQPOOrxuAadTeJ/India-to-draft-rules-forinstitutional-investors-voting-on-c.html

(21) Guy R. Jubb and Nirmal Mohanty, An Indian Stewardship Code: Imperatives and Challenges, NSE Quarterly, NSE, Centre for Excellence in Corporate Governance, October 2017, No.19

(22) Guy R. Jubb and Nirmal Mohanty, An Indian Stewardship Code: Imperatives and Challenges, NSE Quarterly, NSE, Centre for Excellence in Corporate Governance, October 2017, No.19

(23) Jayshree P. Upadhyay, India to draft rules for institutional investors voting on company matters, https://www.livemint.com/Companies/0teJ9go8GQPOOrxuAadTeJ/India-to-draft-rules-forinstitutional-investors-voting-on-c.html 
(24) G20/OECD Principles of Corporate Governance, OECD, September 2015, https://www.oecd.org/daf/ca/Corporate-Governance-Principles-ENG.pdf

(25) G20/OECD Principles of Corporate Governance, OECD, September 2015, https://www.oecd.org/daf/ca/Corporate-Governance-Principles-ENG.pdf

(26) Uday Kotak, Report submitted by the Committee on Corporate Governance, October 2017, http://www.nfcg.in/UserFiles/KOTAKCOMMITTEREPORT.pdf

(27) Uday Kotak, Report submitted by the Committee on Corporate Governance, October 2017, http://www.nfcg.in/UserFiles/KOTAKCOMMITTEREPORT.pdf

(28) Uday Kotak, Report submitted by the Committee on Corporate Governance, October 2017, http://www.nfcg.in/UserFiles/KOTAKCOMMITTEREPORT.pdf

(29) Narayanan, N. (2019). India - The Shareholder Rights and Activism Review - Edition 3 - TLR - The Law Reviews. [online] Thelawreviews.co.uk. Available at: https://thelawreviews.co.uk/edition/the-shareholder-rights-and-activism-review-edition3/1173615/india [Accessed 9 Jul. 2019].

(30) G20/OECD Principles of Corporate Governance, OECD, September 2015, https://www.oecd.org/daf/ca/Corporate-Governance-Principles-ENG.pdf

(31) Shah, S. and Bhatnagar, A. (2019). SEBI revises LODR regulations for better corporate governance and transparency | lawstreetindia.com. [online] Lawstreetindia.com. Available at: http://lawstreetindia.com/experts/column?sid=247 [Accessed 10 Jun. 2019].

(32) Guy R. Jubb and Nirmal Mohanty, An Indian Stewardship Code: Imperatives and Challenges, NSE Quarterly, NSE, Centre for Excellence in Corporate Governance, October 2017, No.19

(33) Guy R. Jubb and Nirmal Mohanty, An Indian Stewardship Code: Imperatives and Challenges, NSE Quarterly, NSE , Centre for Excellence in Corporate Governance, October 2017, No.19

(34) Guy R. Jubb and Nirmal Mohanty, An Indian Stewardship Code: Imperatives and Challenges, NSE Quarterly, NSE , Centre for Excellence in Corporate Governance, October 2017, No.19

(35) Guy R. Jubb and Nirmal Mohanty, An Indian Stewardship Code: Imperatives and Challenges, NSE Quarterly, NSE, Centre for Excellence in Corporate Governance, October 2017, No.19

(36) Uday Kotak, Report submitted by the Committee on Corporate Governance, October 2017, http://www.nfcg.in/UserFiles/KOTAKCOMMITTEREPORT.pdf

(37) Guy R. Jubb and Nirmal Mohanty, An Indian Stewardship Code: Imperatives and Challenges, NSE Quarterly, NSE, Centre for Excellence in Corporate Governance, October 2017, No.19

(38) Guy R. Jubb and Nirmal Mohanty, An Indian Stewardship Code: Imperatives and Challenges, NSE Quarterly, NSE , Centre for Excellence in Corporate Governance, October 2017, No.19

(39) Jayshree P. Upadhyay, India to draft rules for institutional investors voting on company matters, https://www.livemint.com/Companies/0teJ9go8GQPOOrxuAadTeJ/India-to-draft-rules-forinstitutional-investors-voting-on-c.html

(40) Circular PFRDA/2018.01/PF/01, Common Stewardship Code, 4th May, 2018, http://www.pfrda.org.in/WriteReadData/Links/Circular-

\%20Common\%20Stewardship\%20Code\%2004-05-186ec9a3b4-566b-4881-b879-

c5bf0b9e448a.pdf

\section{REFERENCES}

[1] Bhandari, P., (2018). Corporate Governance A Comparative Analysis in India and the US, Honors Projects in Accounting. Paper 19.

https://digitalcommons.bryant.edu/honors_accounting/19 [Accessed 21 January 2019] 
[2] Caldwell, C., Hayes, L.A., Bernal, P. and Karri, R., (2008). Ethical stewardship-implications for leadership and trust. Journal of business ethics, 78(1-2), pp.153-164.

[3] Davis, J.H., Schoorman, F.D. and Donaldson, L., (1997). Toward a stewardship theory of management. Academy of Management review, 22(1), pp.20-47.

[4] Hill, J. (2017). Good Activist/Bad Activist: The Rise of International Stewardship Codes. Legal Studies Research Paper. [online] Sydny: European Corporate Governance Institute. Available at: https://ecgi.global/sites/default/files/working_papers/documents/hillincl-sydney-cover.pdf [Accessed 8 Apr. 2019]

[5] Kaur, R., Kaur, T. and Singh, H., (2018). A Literature Review in the Chronology of Corporate Governance Evolution in India. International Journal on Global Business Management \& Research, 7(3), pp.1-9.

[6] Sarkar, J. and Sarkar, S., (2012). Corporate governance in India. SAGE Publishing India.

[7] Selarka, E. (2019). Corporate Governance Practices in India. [ebook] Chennai: MADRAS SCHOOL OF ECONOMICS, pp.12-33. Available at: http://www.mse.ac.in/wpcontent/uploads/2018/08/Working-Paper-173.pdf [Accessed 6 Jun. 2019].

[8] Sundaramurthy, C. and Lewis, M., (2003). Control and collaboration: Paradoxes of governance. Academy of management review, 28(3), pp.397-415.

[9] Subramanian, S., (2018). Stewardship Theory of Corporate Governance and Value System: The Case of a Family-owned Business Group in India. Indian Journal of Corporate Governance, 11(1), pp.88-102.

[10] Uzma, S.H., 2018. Corporate governance practices: global convergence and Indian perspective. Qualitative Research in Financial Markets, 10(3), pp.285-308. 